\title{
Inconclusive evidence puts Adderall back on the market
}

Health Canada has reintroduced Adderall (amphetamine salts) to the Canadian market after an independent panel found it impossible to accurately ascertain whether the drug increases the risk of cardiac death.

Adderall, a central nervous stimulant used in treating attention-deficit hyperactivity disorder (ADHD), was taken off the market in February after manufacturer Shire Biochem Inc. disclosed 20 sudden deaths and 12 strokes worldwide among patients taking the drug, or its onea-day formulation Adderall XR (the only version sold in Canada).

Shire appealed the Health \& Canada decision, and an external 3-member New Drug Committee was struck to determine whether Adderall was riskier than other ADHD drug therapies.

The committee, chaired by pharmaco-epidemiologist Dr.
Mitchell Levine, director of the Centre for Evaluation of Medicines at St. Joseph's Healthcare in Hamilton, Ont., came down squarely on the fence. Levine's panel concluded Health Canada and Shire used different data sets for their risk analysis and that both used methodologically weak analyses, although Health Canada acted properly in withdrawing the drug as a precaution.

It was impossible to prove or disprove that using Adderall increases the risk of sudden cardiac death, stroke, or both, particularly in children, Levine says. Nor was it possible to determine whether Adderall XR "was particularly worse or more harmful."

The committee concluded that it is "biologically plausible" that there is an increased risk of adverse events from using any stimulants to treat $\mathrm{ADHD}$. But, in light of the uncertainties, it recommended Adderall be reinstated on the market as long as a revised label cautioned against the drug's use by patients with structural heart abnormalities.

Given that safety can't be adequately evaluated, Levine says before prescribing, physicians should consider obtaining a baseline ECG for patients with a family history of pediatric heart failure, who regularly undergo strenuous exercise, or who have congenital abnormalities.

Health Canada adopted the committee's recommendations.

"What else could we do?" asks Dr. Marc Berthiaume, director of the Marketed Pharmaceutical Division. In the absence of a conclusive cohort study, at least "awareness of the issue has been raised."

Shire says adequate supplies of Adderall will be available in Canada this month. - Wayne Kondro, Ottawa

\section{News@ a glance}

Potential cure for HIV: Researchers in Texas have found that valproic acid can awaken dormant HIV infection in cells, meaning HIV may become curable. Their proof-of-concept study (Lancet 2005;366:549-55) showed the number of HIV infected cells in 3 of 4 patients studied declined substantially I $16-18$ weeks $(75 \%$ average reduction) after the start of valproic acid, a commonly used $\tilde{o}$ anticonvulsant. Patients had $\stackrel{?}{0}$ been stabilized on highly active antiretroviral therapy (HAART)

first. Valproic acid stops histone

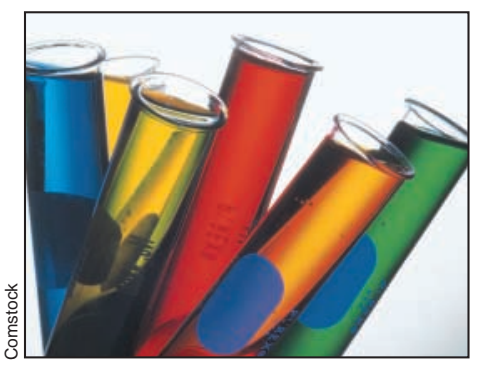

deacetylation, a process that allows HIV to "rest" in cells. If $\mathrm{HIV}$ is unable to lie dormant in cells, all HIV can be killed with HAART. As a result, patients may no longer require lifelong therapy to treat reactivated virus, effectively cured. - Sally Murray, CMAJ

Tell the CMA: The Canadian Medical Association is sending a letter to members asking for their view of the private-public health care debate. In August, CMA General Council passed several resolutions ( $C M A \mathcal{A}$ 2005:173:565) supporting a strong publicly funded health care system, but also allowing that "when timely access to care is not available within [that system], patients should be able to use private insurance." In the letter, CMA President Dr. Ruth Collins-Nakai asks for physicians' opinion to help guide the association's policy principles. Email: yourvoice@cma.ca or votrevoix@cma.ca

Sports and tobacco: The Quebec Court of Appeal has struck down a long-standing law prohibiting the name of a tobacco firm from being associated with a public event. Three tobacco companies - JTI-Macdonald Corp., Rothmans, Benson \& Hedges Inc., and Imperial Tobacco Canada Ltd. - claimed the law restricted their freedom of expression. Mr. Justice Andre Brossard wrote that the existing law goes too far and that there is no harm in allowing a corporation to use its name when that name "bears no harmful connotation." Garfield Mahood of Canada's Nonsmokers Rights Association says this "loophole" can be "exploited by the industry to buy legitimacy." - Compiled by Barbara Sibbald, CMAJ 